\title{
Patagonia
}

\section{Driving Sustainable Innovation by Embracing Tensions}

O'Rourke, Dara; Strand, Robert

Document Version

Accepted author manuscript

Published in:

California Management Review

DOI:

$10.1177 / 0008125617727748$

Publication date:

2017

License

Unspecified

Citation for published version (APA):

O'Rourke, D., \& Strand, R. (2017). Patagonia: Driving Sustainable Innovation by Embracing Tensions. California Management Review, 60(1), 102-125. https://doi.org/10.1177/0008125617727748

Link to publication in CBS Research Portal

\section{General rights}

Copyright and moral rights for the publications made accessible in the public portal are retained by the authors and/or other copyright owners and it is a condition of accessing publications that users recognise and abide by the legal requirements associated with these rights.

Take down policy

If you believe that this document breaches copyright please contact us (research.lib@cbs.dk) providing details, and we will remove access to the work immediately and investigate your claim. 


\section{Patagonia: Driving Sustainable Innovation by Embracing Tensions}

\section{Dara O'Rourke and Robert Strand}

Journal article (Accepted manuscript)

CITE: O'Rourke, D., \& Strand, R. (२017). Patagonia: Driving Sustainable Innovation by Embracing Tensions. California Management Review, 60(1), 102-125. 001: 10.1177/0008125617727748

\section{Copyright [C The Regents of the University of California 2017.}

Reprinted by permission of SAGE Publications.

DOI: 10.1177/0008125617727748

Uploaded to Research@CBS: December २018 


\section{Patagonia: Driving Sustainable innovation by Embracing Tensions Dara O'Rourke1 and Robert Strand ${ }^{12}$}

\section{SUMMARY}

This article examines the tensions that arise when Patagonia simultaneously pursues sustainability and quality objectives embedded within its mission statement: "Build the best product, cause no unnecessary harm, use business to inspire and implement solutions to the environmental crisis." Specifically, this case study focuses on Patagonia's durable water repellent (DWR) problem. DWR is a highly effective chemical treatment used to waterproof jackets (supporting the quality objective) but has by-products that are toxic and persist in the environment (undermining the sustainability objective). This case explores the challenges Patagonia has faced and presents some creative solutions to them.

KeYwoRdS: sustainability, innovation, supply chain, environmental responsibility

Without a healthy planet, there are no shareholders, no customers, no employees. ${ }^{1}$ If we wish to lead corporate America by example, we have to be profitable. ${ }^{2}$

—Yvon Chouinard, Founder of Patagonia

\footnotetext{
1 University of California, Berkeley, Berkeley, CA, USA

2 Copenhagen Business School, Copenhagen, Denmark
} 
A team of Patagonia leaders and key employees were gathering in a sun- filled conference room in their Ventura, California, headquarters. The morning surf was particularly good that day, which meant start times for meetings were more of a suggestion than a rule. During this meeting, the team planned to discuss numerous real-time issues, one of which was a recent Greenpeace study that found traces of perfluorinated compounds (PFCs) in the waters of high-altitude lakes around the world.

For years, Patagonia had urgently sought to rethink the durable water repel- lent (DWR) treatments derived from PFCs that they used to make high-perfor- mance outerwear waterproof. The Greenpeace study illustrated why the project was a top priority. While existing DWR chemicals offered exceptional performance of Patagonia's products, particularly in extreme conditions, and allowed Patagonia gear to last for years, the by-products of these chemicals were toxic and persisted in the environment, and thus made their continued use unacceptable. While using any PFCs fulfilled one aspect of the company's mission — building the best prod- uct — doing so failed to uphold the company's environmental commitments, lead- ing to a major tension between quality and environmental harm.

However, related to DWR, shortened life spans of products were of special concern for the company. A rain shell that stopped preventing saturation func- tionally degraded into a wind shell long before the garment itself wore out. The garment thus needed to be replaced more frequently, which constituted its own environmental problem- every replacement garment came with its own environ- mental cost in energy and water used, and waste and greenhouse gases gener- ated-so sacrificing garment life was a serious trade-off for the company.

The DWR that Patagonia as well as other high-quality outdoor outerwear suppliers used as a standard for years was a long-chain (C8) fluorocarbon-based treatment that was highly effective and extraordinarily durable. Unfortunately, as mentioned above, its by-products were toxic and persisted in the environment, a combination that made it unacceptable despite its excellent performance.

Patagonia's temporary solution was to switch from a C8 fluorocarbon- based treatment to a shorter chain C6 treatment, also fluorocarbon-based, but with byproducts that broke down faster in the environment and with less poten- tial toxicity over time to humans, wildlife, and fish.

Patagonia's mission statement is to "Build the best product, cause no unnecessary harm, use business to inspire and implement solutions to the environmental crisis." 3 Over the last five years, Patagonia had refused to agree to calls by nongovernmental organizations (NGOs) to eliminate PFCs from products on the 
grounds that this would compromise Patagonia's ability to "build the best product"resulting in more gear tossed into landfills and requiring replacement. This also contributed to Patagonia's decision not to join ZDHC (Zero Discharge of Hazardous Chemicals), an organization focused on leading the industry toward a reduction in the use of hazardous chemicals by 2020 .

As the Patagonia team discussed their ongoing path to address the tensions that arose between the company's desires for performance, durability, and their commitment to cause no unnecessary environmental harm, they wondered how Patagonia could most effectively embrace these tensions to drive innovation to solve the DWR challenge, and to "use business to inspire and implement solutions to the environmental crisis."

\section{Patagonia's Background and Early History}

Patagonia was born out of legendary rock climber Yvon Chouinard's inability to find high-quality pitons (pegs or spikes used to drive into a rock or crack to support a climber or a rope) for rock climbers. ${ }^{4}$ As word spread about Chouinard's pitons, he sold them out of the back of his car and off of a blanket in Yosemite for $\$ 1.50$ each. In 1965, he partnered with fellow climbers Tom and Doreen Frost to create Chouinard Equipment and, by 1970, the company was the largest supplier of climbing hardware in the United States. Initially, the com- pany was simply a way to pay their bills and they took turns minding the com- pany while going on climbing trips.

In 1985, Patagonia began donating $1 \%$ of its total sales to environmental organizations through $1 \%$ For the Planet. Chouinard said,

You have to get away from the idea that it's philanthropy. I look at it as a cost of doing business. Every business should say, "We're polluters, we're using our nonrenewable resources, and therefore we should tax ourselves." Being part of $\left[1 \%\right.$ For the Planet] is also good for business .. Think of it as a marketing cost. ${ }^{5}$

Between 2009 and 2013, Patagonia's revenue doubled to over $\$ 500$ mil- lion, and by 2015 surpassed $\$ 600$ million with over 2,000 employees. However, even with this growth, the company was still much smaller than competitors such as The North Face and Columbia, who had $\$ 2$ billion and $\$ 2.3$ billion in sales, respectively. ${ }^{6}$ Over the past 30 years, the company has given over $\$ 60$ million in cash and in-kind donations to environmental causes and over 1,000 organiza- tions. The company also helped launch two other North American business phi- lanthropies - the Conservation Alliance ${ }^{7}$ and $1 \%$ For the Planet (launched in $1985^{8}$ ), as well as the European Outdoor 
Group's Association for Conservation and the Organic Exchange (now Textile Exchange).

In 2011, Patagonia became a B-Corporation. ${ }^{9}$ Through this, Patagonia further solidified its reputation not only for its innovative designs and quality prod-ucts in the outdoor and everyday clothing, gear, and food industries but also for its environmental and social conscience.

The company's four core values are as follows:

1) Quality: Pursuit of ever-greater quality in everything we do; 2) Integrity: Relationships built on integrity and respect; 3) Environmentalism: Serve as a catalyst for personal and corporate action; and 4) Not Bound by Convention: Our suc- cess-and much of the fun-lies in developing innovative ways to do things. ${ }^{10}$

In his book, Let My People Go Surfing, Chouinard outlined the company's environmental philosophy: "Lead an examined life; Clean up our own life; Do our penance; Support civil democracy; and Influence other companies.”11

\section{Tensions between Supply Chain and Sustainability}

Patagonia has lived with the tension between performance and environ- mental impact almost since its founding. According to Matt Dwyer, Director of Materials Innovation \& Development, "When they do cross, very magical things happen. If we find something that provides a ridiculous performance benefit and also has a significantly reduced environmental impact, that's the sweet spot for new disruptive innovations." On the mission statement, Dwyer added,

We are explicitly trying to build the absolute best product in terms of durability, functionality, fit, multi-functionality, as well as the design attributes such as being long-lasting, timeless, durable, and doing exactly what we say it will. This is hands down the number one goal. We continuously look for ways to minimize environmental harm while building the best product.

Doug Freeman, Patagonia's COO, said on Patagonia's supply chain strategy:

We chase quality and build products that are responsible. We make decisions in the supply chain that link up raw materials sources close to the factory that we're manufacturing in. We are very good at defining what it is about that product that will make it best available to consumers. We look for partners that are long-term, sophisticated, have deep resources, and have operations in many countries. We like a consolidated supply chain - to be bigger presences in the factories that we are 
manufacturing in (although we cap our presence at 25 percent of a factory's business because if we were to leave, we would displace a lot of people). We like to know how the people in the supply chain are being managed. We care deeply about our environmental footprint and we want to build the best product that will be used by people for a very long time - we are against fast fashion and landfills, which lead to our $\mathrm{CO}_{2}$ problem. We are very proud that some of our most popu-

lar styles such as our Snap-T fleece and Baggies are styles we introduced 20 to 30 years ago.

One of Patagonia's supply chain challenges was managing the tensions between the sourcing people (who were focused on price, delivery times, and volume), the quality people, and the compliance people. "It's a tough conun- drum," said Freeman.

You're off balance all the time. We are dealing with a factory in the Philippines who makes our climbing gear, which is important to our business. It's about appealing to the factory to do the right thing. It's about bringing the suppliers into the conversation and telling them how our business together will grow while tell- ing them that we see overtime in the workers which we don't like, and people being hired by employment agencies while we would prefer to see them working full-time. Seasonal workers in our industry, where we make 60 percent of our sales in the fall season (versus other outdoor companies that are at 90 percent), are a reality, but we have to appeal to these factories to do the right thing. It takes a lot of time and it's really frustrating.

How Patagonia developed its supply chain strategy and executed upon the strategy was organic, democratic, and decentralized, according to Freeman who joked that the company was the "Socialist Republic of Patagonia."

As a management team, we try to empower people to make good, collaborative, and very transparent decisions around the values of the company. It's unique and unlike any company I have ever worked at in that we treat quality, best product, the environment, and the social issues that affect the people in the supply chain on an equal level as the business of the company.

This meant that a director representing social and environmental responsibility, a quality person, a sourcing manager, and a sourcing director, each had equal say on which factories Patagonia worked with (or did not work with). Freeman added, "Most conversations in the apparel industry begin and end around price, minimum quantity, and lead time; ours begin and end around qual- ity, social and environmental responsibility, and best product."

On the strategy of sustainability, Rick Ridgeway, Vice President of Public Engagement, said,

Central to the evolution of my own position at Patagonia is the strategy of decen- 
tralizing and integrating sustainability within the organization. That's a big deal. It's the natural evolution of any company's commitment to sustainability that's genuine. If a company's really going to embrace sustainability issues, then it has to figure out how to integrate it into the warp and weft of the organization.

In that spirit, the BUDs (Business Unit Directors of each area such as surf, sportswear, alpine and snow, fieldwear, fishing, and military), PLMs (product line managers), and designers were sometimes the ones who championed certain new technologies or materials such as Yulex wetsuits and lower impact DWR alternatives. "That's what we hire our BUDs to do," said Freeman. Jill Dumain, Director of Environmental Strategy, added that the top was important too, however:

Yvon always said the revolution has to start at the bottom with the people, but then he saw what happened with Walmart and B-Corp ${ }^{12}$ and now we're seeing the top and bottom work together and we're getting squeezed in the middle. ${ }^{13}$

Patagonia's decentralized culture, however, sometimes led to a "lack of decision making," according to Freeman.

Sometimes it's too democratic, too transparent, and people are afraid to make decisions. Sometimes there are too many people in the room and things take a long time. In these cases, the VPs and I say that we need to make a decision and not be so timid.

Freeman also acknowledged that Patagonia was "short-handed" and was doing the best that it could to deal with the number of environmental and social issues within its supply chain, one of which was PETA's (People for the Ethical Treatment of Animals) exposure in 2015 of Patagonia's sourcing of wool from farms in the Ovis 21 network (who mistreated lambs):

We will get caught flat-footed or on our tails. We haven't gotten to the auditing of our shipping lines. We're not getting into how the publisher is treating people within our catalog production. We only have a handful of people dealing with 190 suppliers. We have a toolbox and we opened it up to the industry, ${ }^{14}$ but it's naïve to think we have everything figured out.

Patagonia recently invested in sustainability and EHS ${ }^{15}$ management software that would help to measure water, energy, waste, and greenhouse gas emis- sions from a supply chain and at a corporate level. "We're trying to make supply chain decisions that lessen our dependence on water," said Freeman. "A lot of what our team is focused on is new technologies, water-free dyeing, and textiles, as well as bio-based technologies that impart PFC-free finishes on textiles, particu- larly on waterproof breathables." Freeman hoped that the software tools that Patagonia implemented 
would help the company decide what areas to invest in through \$20 Million \& Change, its new venture arm. "Up until now, deciding what to focus on in the supply chain has been gut instinct and what we've been reading," he said.

The materials group, headed by Matt Dwyer, had two "umbrellas" to help frame projects and initiatives to focus on-environmental issues such as waste, water, energy, and emissions; and high performance, which consisted of projects that focused on performance attributes or new cutting-edge technologies for ath- letes. Ridgeway acknowledged, "We, to a fault probably, do spread ourselves pretty wide — but our efforts and initiatives are all guided by our mission."

\section{DWRs}

By 2015, one of Patagonia's (and the industry's) pressing environmen- tal, health, and supply chain problems was the use of DWRs on outerwear such as jackets. Conventional DWR treatments involved the surface application of a long chain of fluorocarbons (such as C8) onto a fabric that were highly effective and durable, but that produced by-products that were toxic and persistent in the environment (in animals and humans).

C8 was a type of fluorocarbon or PFC that was petroleum-based and used in various other consumer products such as nonstick cookware, paints and coat- ings, and stain-release treatments for carpet. Patagonia was not aware of any links between increased fluorocarbons such as $\mathrm{C} 8$ in the body due to skin contact from its clothing. "But because we are concerned about the persistence of these chemi- cals in the environment, we have been working to find alternatives to two fluori- nated compounds: perfluorooctane sulfonate (PFOS) and perfluorooctanoic acid (PFOA), which was a by-product of C8."16

Companies traditionally used C8 because of its effectiveness-strong, longlasting surface compounds that allowed rain or water to bead up and disperse, essentially waterproofing clothing and jackets, while allowing the fabrics to remain breathable. As Tetsuya Ohara, Patagonia's Director of Innovation Research, explained, "DWR is so important in outdoor gear because people go to inclement weather like snow or rain and if the gear naturally 'wets out,' it reduces human temperature and energy and that can be dangerous."

Both PFOS and PFOA have been identified by preliminary government- risk assessments as being consistent with a category of a "likely carcinogen." PFOS levels have been found in wildlife, and higher levels of PFOS in humans could lead to 
chronic kidney disease. ${ }^{17}$ Likewise, PFOA persists indefinitely in the envi- ronment and is a toxicant and carcinogen in animals. PFOA has been detected in the blood of more than $98 \%$ of the general U.S. population. PFOA has been detected in industrial waste, stain-resistant carpets, carpet-cleaning liquids, house dust, microwave popcorn bags, water, food, some cookware, and Teflon. ${ }^{18}$

In 2011, a Greenpeace campaign called "Detox" targeted a group of major apparel and footwear brands and retailers around their use of toxic chemicals. In response, the industry came together to form ZDHC, an organization focused on leading the industry toward zero discharge of hazardous chemicals by 2020 . Members included Nike, Adidas, H\&M, Gap, Puma, and others. However, none of the major outdoor companies initially joined this organization as they argued their performance standards for their clothing and outerwear were too strict to move away completely from PFCs.

Legislation, however, soon caught up with the entire industry and took over as the key driver of DWR issues. For example, the European Union has banned PFOS and PFOA. In the United States, the Environmental Protection Agency (EPA) initiated a voluntary industry phaseout of PFOA, and the major global fluorochemical companies (eight of them) have agreed to eliminate PFOAs by $2015 .{ }^{19}$ In the United States, the EPA has banned PFOS since 2000 (except for special uses in aviation, photography, and microelectronics). In 2000, 3M stopped making PFOS and eliminated it from its Scotchgard fabric protector. In 2003, DuPont had class-action lawsuits filed against it for its use of PFOA for Teflon on cookware and was in the process of eliminating PFOA from its products.

Australia has issued two alerts on PFOS, recommending use only in essential cases. In June 2005, Sweden proposed a global ban on PFOS. In 2005, the European Commission (EC) issued a proposal for a Directive to restrict the use of PFOS in carpets, textiles, and other clothing. In 2014, Norway banned PFOA in consumer products.

NGOs also had an active role in DWR awareness. In 2012, Greenpeace Germany published a report, "Chemistry for Any Weather," that summarized the findings of two independent labs it commissioned to evaluate the chemical con- tent of outdoor weatherproof clothes by manufacturers such as Patagonia, The North Face, Marmot, and others. The labs found PFCs in all 14 samples and high concentrations of PFOA/C8 (for water resistance) in all samples. Kirsten Brodde of Greenpeace said,

There are no safe levels for PFCs; they are intrinsically hazardous and should be eliminated completely by the textile industry. An outdoor industry that draws a picture of itself as being green should stay out of the use of all hazardous chemi- cals 
and not try to ... slow down the process of elimination. ${ }^{20}$

At the time of the Greenpeace study, Patagonia was in the process of eliminating PFOAs from all of its products by 2015 and converting $40 \%$ of its DWR products to shorter chain C6 technology (see below for discussion of C6).

In 2015, Greenpeace released another study that found traces of PFCs in the waters of high-altitude lakes around the world, from the Torres del Paine National Park in Patagonia, Chile, to the Lago di Pilato in the Apennine mountain range in Italy. Greenpeace said its study proved how slowly PFCs break down in the environment. "It is ironic to think that companies who depend on nature for their business willingly release dangerous chemicals into the environment," said Mirjam Kopp of Greenpeace. "They need to set short-term deadlines for com- pletely eliminating the entire group of PFCs in production processes." ${ }^{21}$ Greenpeace praised Puma and Adidas for their "ambitious elimination targets" for PFCs from its clothing through ZDHC. However, Greenpeace felt that The North Face, Columbia, Patagonia, Salewa, and Mammut were not moving quickly enough.

Freeman said on NGOs:

Greenpeace is really upset that PFCs are showing up in our bodies and the envi- ronment. We agree that this is not okay. I'm appreciative of what PETA and Greenpeace bring because they bring awareness and it sparks ingenuity, but it can be a painful process.

Dwyer said,

DWR is definitely an instance where innovation had to happen in the wrong way, where all of a sudden there was extreme scrutiny on a key component of every- one's product line. In real life, I prefer that we saw this coming and when the legislation happens, we're already doing the right thing. That's our strategy today.

\section{C8 Alternatives}

For years, Patagonia has been researching and testing fluorocarbon-free chemistries (a dozen or more) such as waxes and silicones that also allow water to bead up and disperse versus saturating/wetting out. However, according to the company's blog, waxes and silicones

are easily contaminated by dirt and oil and rapidly lose their effectiveness, reduc- ing the effective lifetime of a garment. The short life span is of special concern. 
A rain shell that stops preventing saturation functionally degrades into a wind shell long before the garment itself wears out. The garment must be replaced more frequently, which constitutes its own environmental problem. Every replace- ment garment comes with its own environmental cost in energy and water used and waste and greenhouse gases generated. So sacrificing garment life is not an option. ${ }^{22}$

Many fashion companies were also "actively pursuing non-fluorinated applications," according to Nike's John Frazier. ${ }^{23}$ Dow Chemical provided siliconebased treatments and more limited performance solutions such as wax and oil- based finishes. But again, companies such as Nike did not have the same weather performance requirements as Patagonia or The North Face. And these treatments were not "new" innovations, but rather recycled ones from decades ago that had been phased out when PFCs first became popular.

Very large chemical companies such as Dow and DuPont (through its Chemours spin-off), along with specialty chemical companies such as Huntsman, were also researching more effective DWR alternatives. To date, however, their solutions have been chemical-based such as shorter chain fluorocarbon-based polymers like C6 (also sprayed on), but with by-products that broke down faster in the environment and had "less potential toxicity over time to humans, wildlife, and fish." 24 According to Patagonia, the problem was that outerwear using C6 was not as effective and in torrential rains, for example, wet out more quickly.

Robert Buck at DuPont said that companies like his were focused on shorter chain polymers, but acknowledged that questions about their toxicity remained. ${ }^{25}$ Ohara said, "For chemical companies, this is their business - they have to sell chemicals so the approach to solve problems is to always use chemicals."

Over the past four years, Patagonia has transitioned its product line to shortchain DWRs, and by spring 2016, $100 \%$ of its line will be transitioned. ${ }^{26}$ According to Patagonia,

The majority of our current products that are treated with DWR now use C6 fluorocarbon-based water repellents. These are PFOS-free, but PFOA is still detectable on the treated fabric at around $100 \mathrm{ppb}$ (parts per billion). One ppb is comparable to one second in 32 years. It's a very small amount. ${ }^{27}$

Matthias Foessel, CEO of Beyond Surface Technologies (BST; see below), said,

The problem that I see is that moving from C8 to C6 is not solving the issue. If you're 
really concerned about PFOA and if your intent is to go PFOA-free, then your only choice is to walk away from PFCs entirely. ${ }^{28}$

Since switching over to shorter chain chemistries for its DWR treatments, Patagonia has not heard any negative feedback (its Torrentshell jacket, for example, was switched over to shorter chain chemistries in the 2014 line), accord- ing to Dwyer:

I actually expected to have heard from customers by now, but we haven't heard many performance-related complaints yet. Part of it is that we spent seven years working with key suppliers on our fabrics at the mills doing the trials with the chemistry to make sure we were sacrificing the least in terms of performance. We're actually pretty happy with the quality right now.

\section{Investing in DWR Science: BST}

In 2013, Patagonia launched an investment venture arm, "\$20 Million \& Change," which invested in responsible and disruptive startups (in food, water, energy, and waste). For apparel, this meant investing deep within the sup- ply chain in search of disruptive technologies and sustainable eco-innovations. By 2015, the company had made ten investments. One example was a project in Chile that made skateboards out of discarded fishing nets. Another was an investment in $\mathrm{CO} 2 \mathrm{Nexus,}$ a company that has developed a sustainable method of processing (cleaning, disinfecting, and coating) textiles and garments using liquid carbon dioxide-using zero water, consuming less energy, and generating very little waste. Another investment in 2015 was $\$ 1.5$ million in a Swiss com- pany, BST, that worked to reduce the impact of textile chemicals on the environ- ment through natural raw materials. The BST investment was the second largest investment outside \$20 Million \& Change's investment in its solar fund. ${ }^{29}$

Phil Graves, Director of Corporate Development, who ran \$20 Million \& Change said,

\$20 Million \& Change is very different from the traditional VC model that is focused on exits through IPOs or acquisitions, which we believe is a broken model. When VCs get involved, they typically put a spotlight on a startup's short- term growth and profitability, which makes it difficult for an entrepreneur to stay true to their environmental or social mission. Instead, we invest for the long haul and aren't tied to a target rate of return over a set holding period. For each invest- ment, we do the standard commercial, financial, and legal due diligence, but we also spend a lot of time on environmental and social due diligence by examining a company's entire supply chain. We also have annual summits where we huddle up with our entrepreneurs and share environmental best practices. 
Although some other companies had corporate venture arms like Patagonia's, Graves said that they tended to focus on a single bottom line: profit. Meanwhile, \$20 Million \& Change focused on multiple bottom lines such as peo- ple, planet, and profit. So far, \$20 Million \& Change has achieved healthy finan- cial returns, although that was not the primary goal of the fund.

BST, a textile firm, was founded in 2008 by former Pfersee $\mathrm{GmbH}$, Huntsman, and Ciba-Geigy scientists and employees, and by 2015 it had 20 employees (of which two were PhDs and four were textile chemists, including the CEO himself). With the help of BST, Patagonia hoped to eradicate fluorocarbons related to waterproofing apparel. BST CEO Mathias Foessel ${ }^{30}$ said,

We started BST to see, within the textile chemical business, whether we could approach it differently and come up with better ideas instead of always starting with crude oil-based raw materials, and come up with new technologies that are based on renewable raw materials that are also cost-competitive.

Ohara said, "A smaller start-up like BST can revolutionize the industry, whereas chemical companies cannot."

By 2015, BST had three different bio-based products, of which some were used by Patagonia, Levi's, Mammut, Adidas, Nike, and Puma. Midori Biosoft was a plant seed oil-based wicking finish used on base layers, Midori Biolink was a natural acid-based finish for denim (that does not use conventional formalde- hyde), and Midori Evopel was a partially natural-based DWR for waterproof- breathable shell fabrics. Biosoft was used in Adidas' products for cycling or running. Biolink was used in Levi's products and those of many smaller compa- nies. Patagonia was interested in all products, but especially in Evopel (which was not a commercial product yet) due to its potential impact on Patagonia's DWR challenge. Also by 2015 , the company was cash-positive and was generat- ing a profit.

BST used agricultural and algal products as feedstocks/raw material and did not use GMOs. The weakest of the three products was Evopel because it relied on a mix of crude- and bio-based feedstocks (the other products were $100 \%$ bio- based while Evopel was around 50\%-60\% bio-based), and Evopel was not as reli- able as conventional waterproofing chemicals.

Foessel explained,

We needed durability and water-repellency and based our current formulation on an acrylic backbone (similar to C8) and a different mix of hydrocarbons for the water- 
repellency. The hydrocarbons are the renewable part of the product and the acrylic is the non-renewable. Chemically, with that kind of approach, we can't compete performance-wise with PFCs. The hydrocarbon group has a lower perfor- mance and we don't get the kind of branching of the side chains as in PFCs so it's not as robust in heavy rain and during laundering.

Graves added, "In the meantime, we suggested to BST to look at commercial opportunities for Evopel in other applications such as baggies and board shorts, which don't require as rigorous science and that's what BST is looking at now."

Moreover, BST was also looking at other options to make the side chains more robust in terms of waterproofing (with a new undisclosed component) as an interim step to reduce the percentage and amount of PFCs used in a particular garment. Foessel explained,

We have talked to Patagonia that we could use some of our new research that we're working on for a phased approach to significantly reduce the amount of PFCs used (compared to what is used today), but not impact the current perfor- mance at all. Maybe we can halve the volume of PFCs needed [due to mixing with the new undisclosed component] without compromising any performance. The question is whether we can get a DWR, at least from a water repellent perspective, to the level of performance that PFCs offer today. It's a question mark because we're not there yet.

According to Patagonia,

The mission of Beyond Surface Technologies aligns well with ours. They [founders of BST] left careers at big chemical companies and now they're doing business on the premise that we can make textile treatments based on natural raw materials without sacrificing performance or reducing the lifespan of our products. We see great promise in this new partner's potential to invent ways to make our garments waterproof using safe, fluorocarbon-free chemicals without compromising performance and durability. ${ }^{31}$

Rose Marcario, Patagonia's CEO, added,

This is the tension we feel every day, making the best technical products for our core sports and working to fulfill our environmental commitments. BST has the potential to help Patagonia and our entire industry get to the next level of chemi- cal safety without compromising performance, and we're very excited to invest in their success. ${ }^{32}$

Both Graves and Ohara felt that BST's founders had strong backgrounds and “could go against anyone," said Graves. But any project could potentially fail: 
Sure, they could fail on DWR, but they are working on other bio-based solutions, such as wicking, anti-microbial, etc. If they hit a homerun in any of these areas - or any other future development - then it's a good investment for Patagonia and the planet.

Ohara added, "BST is definitely the front-runner, but no one is sure." Foessel said on competition: "While every textile chemical supplier is working on the DWR problem, I'm not aware of anyone approaching it like we are."

The BST investment complemented Patagonia's own internal efforts, which included hiring three materials innovation engineers who had PhDs. He said that competitors such as The North Face, Columbia, and Arc'teryx had smaller materials staff. Graves said, "We have a lot of expertise with product design, functionality, and testing. When we work together with our investment partners like BST, we can take their innovations, test them, and work together to refine them."

Foessel added,

What's helpful to us is that the sooner we can put a product candidate on a real garment, the shorter our development times will be. We can go to Patagonia any- time to test on real products. If we didn't have that opportunity, we might do R\&D for another six months and discover that it doesn't work and we would lose six months for nothing.

Both BST and Patagonia had a dedicated representative that coordinated their joint projects and who had monthly or more calls.

Foessel said that they chose Patagonia to work with because they wanted to have certain freedoms:

We have turned down other investors who wanted to take a larger role, and we declined because we felt it was important to keep the freedom of being able to work and test what we want to, and even fail and come back and restart. That's part of the fun. We have to be independent in our decision making. We have a high rate of failure, and if there was someone in the back room trying to veto ideas, we'd not have gotten here. ${ }^{33}$

Likewise, Graves said it took a "long time" for the BST team to "get comfortable" with Patagonia because they were protective of whom they wanted to partner with. "They were very transparent about how long it could potentially take (one year+) to find a DWR drop-in solution and that they might never find one," said 
Graves. "I appreciated BST's honesty. The beauty of \$20 Million \& Change is that we don't have to return capital to anyone in the near term. Sometimes the solutions you are looking for take time."

Graves said that much due diligence went into selecting BST as a partner, including research, interviewing industry experts, and internal knowledge, "so we can figure out what's greenwashing and what's not." He added,

We only invest in partners that are 100 percent aligned on mission and values. Wealso have a sweet spot where the company is not only like-minded, but also small enough that our investment would provide meaningful capital to them.

Ohara's innovation and research team had initially found BST, conducted the due diligence, worked with Graves in \$20 Million \& Change, and "handed over" the project to Patagonia's Materials Innovation Team.

\section{"Blue Sky" Innovation at Patagonia}

Beyond Patagonia's investment in BST, the company also focused on long- term "blue sky" eco-innovation projects. In his role as Patagonia's Director of Innovation Research, Ohara "built a vision of long-term radical eco-innovation for the company's product lines and new business." ${ }^{34} \mathrm{He}$ focused on materials and new construction methods. Ohara said that other outdoor companies might have similar roles as his, but most were "gimmicks and marketing-driven to cre- ate stories."

Innovation decisions were driven by macroenvironment factors such as water shortages, climate change, exchange rates, and oil prices, which all affected Patagonia's business and innovation. "We analyze the past to understand patterns and we predict the future to determine what areas we should focus on such as clean innovation," said Ohara. However, research and innovation choices also needed to meet Patagonia's design philosophy_ “simplicity, functionality, and versatility" - as well as the mission of the company.

Ohara said that $90 \%$ of Patagonia's innovation was "sustaining innova- tion," meaning incremental tweaking of existing products based on consumer feedback (Patagonia received feedback constantly through its customer service center and during its biannual Global Sales Meeting in Ventura where sales people from all over the world shared their feedback). The remaining $10 \%$ was the blue sky innovation within Ohara's team. Dwyer said on sustaining innovation: 
It's about collaborating with partners who are good at what they do and have pro- cess and chemistry knowledge, paired with our expertise on end-use, the athlete, product construction, and our product expectations, that's where the sustaining innovation is going to come from-especially now that we're not using C8 any- more and products are more finicky in terms of textile construction and how it's handled and cared for.

Blue sky projects could also develop from Chouinard's international travels and sometimes "he comes back to Ventura and drops a bomb on us," laughed Ohara. "This can be really unpredictable." 35

One example of a blue sky project was an eco-innovation project behind Patagonia's Yulex wetsuit that was made from natural rubber made from Guayule, a native Arizona plant that required no petroleum. Ohara and his team researched plantbased options for wetsuits for four years from 2008 to 2012 and partnered with Yulex, an eco-friendly biomaterial company in 2013. Traditional rubber plants and synthetic rubber production both use environmentally harmful sol- vents and create significant amounts of nonbiodegradable by-products. Yulex's Guayule-based rubber production created only organic by-products and used only water solvents. The Yulex wetsuit was made up of $60 \%$ Yulex and $40 \%$ synthetic rubber. The sustainable wetsuits performed the same in terms of warmth, flexibil- ity, and durability as their petroleum and limestone-based counterparts. However, the Yulex wetsuit retailed at \$529, which was $36 \%$ more than Patagonia's stan- dard neoprene wetsuit.

By fall 2016, Patagonia's entire wetsuit line would be 100\% Yulex. "This is really rare in the apparel industry that usually develops products in six-month cycles," said Ohara. "But we decided that if we do the same things as other companies, we can't differentiate ourselves, so we decided to focus on long-term research."

Another project was R\&D behind Merino Air for base layers where merino wool from the Patagonia region was spun using a proprietary process that increased the yarn's heat-trapping ability without increasing its weight. The Merino Air research took two to three years before Patagonia launched its new product.

\section{Blue Sky DWR Research and Innovation: Biomimicry}

Foessel, of BST, argued that the apparel industry was an "old" industry "doing what they have always been doing," but that "I'm excited about longer- term blue sky innovations." He said,

There are endless opportunities in textiles for better and smarter technologies. I'm 100 percent convinced that the textile industry needs to change fundamentally soon. The 
power to change things fast in the textile industry is with the brands such as Nike and Puma. If they lead, the industry will follow.

On blue sky innovation related to DWR, Ohara's team focused on biomimicry. He explained,

We're working with universities, museums, and institutions to understand how natureplants, insects, and butterflies-learns about hydrophobicity (how a mol- ecule repels from water). It's fascinating how the surface of animals, over the years, has learned how to repel water. We're trying to learn how to apply hydro- phobicity to our products. This is a long-term research project that is a radical new approach.

Ohara said that biomimicry could be applied to DWR, as well as how to maintain warmth, and other areas, not only on the chemistry side but also on the structural side such as how birds fly. "We learned how hollow bones that have a lighter structure can perhaps be applied to surfboards, for example," he said.

Patagonia's interest in biomimicry was sparked by scientists who visited Patagonia 20 years ago to demonstrate their theories on evolution and how nature learns. "We were fascinated," said Ohara, but Patagonia did not have resources until the last few years. "It makes sense for Patagonia to learn from nature and it's the right time."

Since simplicity was part of Patagonia's design philosophy, Ohara and his team were trying to change the surface of materials without any chemistry by creating uneven surfaces to see whether "we can get hydrophobicity without spray treatments." He said, "Nature doesn't use any sprays. This means we need to get special fibers [or] change the fiber structure to create a new weaving struc- ture to see if we can change performance easily."

On the supply chain, Ohara said, "Using our existing supply chain is really important for Patagonia's innovation process. We look for a simple way to solve a big problem - the key component of innovation research."

On the sustaining innovation in DWR, Ohara said,

We can probably improve performance every season incrementally, 10 to 15 per-cent better than last season. We look back five years and it's amazing. I don't think we can introduce dramatic results within a 12-month period, but we can continue to improve 10 to 15 percent each year and, over time, we will have an amazing product. For biomimicry, it's unpredictable, but we might find something interest- ing and try to apply it to our manufacturing process. 


\section{Scaling Patagonia's DWR Solutions}

In line with other environmentally friendly technologies that Patagonia has developed, new technologies related either to BST or Biomimicry that the com-pany could bring to market would be available for use by other companies and even competitors in the industry. Dwyer said, "We want to use business to inspire and this is about proliferating. Nike does in a month for one style what we do in a year-how do we structure our innovations so that they get picked up and scale? A lot of times, we need to spend more money upfront and do more of the work."

Specifically, Patagonia's Annual Benefit Corporation Report stated, "Patagonia may share proprietary information and best practices with other busi- nesses, including direct competitors, when the board of directors of Patagonia deter- mines that doing so may produce a material positive impact on the environment." 36 Ridgeway added, "I may have some ability to move the SAC [Sustainable Apparel Coalition] as an agent that could scale new innovations. Through that position, there's always potential to get companies to scale innovations and advance goals." However, sharing best practices through SAC, Outdoor Industry Association Sustainability Working Group, and Fair Labor Association (FLA) could be slow and challenging. "It's also a challenge to strike the right balance between sharing infor- mation about our business in response to the many requests we receive and getting the work done." ${ }^{37}$

\section{Graves said on DWR:}

Given Greenpeace and others, DWR is a hot button issue that other industry play- ers are going to have to address and adopt new solutions. If BST cracks the code with a biobased DWR that hits the same apples-to-apples performance mile- stones, other players are going to have to adopt it, unless it is 10 times the price. We want to be first to market, but then open source this innovation to the indus- try in order to amplify the environmental benefits.

BST had the freedom to set the prices of its products, but was quite aware of cost issues:

If you had a drop-in solution for PFCs, 10 or 15 years ago, if you were one cent per garment more expensive, brands wouldn't buy from you. That has changed though. If you can come in with a convincing offer, prove you have a product that has a lower impact on the environment, you can get away with a marginal cost increase and still sell, but there's still a limit, depending on the brand. If you doubled the cost, you would have a very limited market.

He added, 
Our approach is that we want to have the same performance, easy implementa- tion for the supply chain, and it should be cost-neutral or marginally higher cost. If we can do that, it should be a no-brainer. We want to make it as hard as possible for brands not to adopt it.

Foessel acknowledged that because of the importance of DWR, BST would still consider disrupting the supply chain with a new machine or a new process.

With DWR, we're not limiting our research on 100 percent straight drop-in solutions. That's our approach for wicking and other things, but for DWR, it's a whole different category and we don't want to constrain ourselves with 100 percent dropins because we might overlook other approaches.

\section{Ohara said on Yulex,}

We are very open to share our environmental platforms so that as an industry, we can clean up traditional problems. In the case of Yulex, how we laminate our wet- suits or how we incorporate special jerseys (used to line the interior of wetsuits) are our competitive advantages that we don't disclose. So the platform we share; the special technologies we don't.

\section{Dumain discussed her views on scaling Patagonia's initiatives:}

We have a long history of sharing information with our competitors. It goes back to organic cotton in the 1990s. I can remember walking around the trade show asking for conversations at different booths to talk about the benefits of organic cotton and why they should adopt it. Now we are doing the same thing with Yulex, the plantderived wetsuit raw material, and our Traceable Down. We are willing to talk to anyone about these projects. It is for two reasons. First, to meet the environmental, social, and animal welfare goals, but we also know that these projects need to scale if they are going to be successful. ${ }^{38}$

\section{Dumain continued:}

We feel like our role as a for-profit company is coming in and starting the con- versation from a business perspective and realizing, forget all the environmen- tal arguments, but we're in a resource-constrained world and there are already starting to be business ramifications from resources being constrained whether it's draught or fire ... For me, even internally, when people ask, "What's the economic case - this all costs more?" Well, it costs more today, but is it going to cost more in 5, 10, 15 years? Are you going to have to shift your supply chain because you're not working with vendors that are efficient with their resources? How does that play into it? How do we create what we need versus what we want in our society? ${ }^{39}$ 
In the case of organic cotton, Patagonia was successful internally by having their entire product line use organic cotton, while the external industry did not embrace the shift for a variety of reasons such as cost and decentralized agricul- ture. With Patagonia's biorubber wetsuit, Quicksilver announced that it planned to use Yulex in its high-end line of wetsuits (although Quicksilver filed for bank- ruptcy in 2015), and several other companies were investigating the new technol- ogy for flip-flops and wetsuits. Graves said,

It does come down to cost. A lot of companies want to do the right thing but are afraid of a negative hit on next quarter's earnings. When we switched to organic cotton in 1996, it initially hurt our bottom line but it was a great decision looking back. Other companies might not be willing to take the long view.

Hub Hubbard, Product Developer of Wetsuits, said,

Patagonia knew from the get-go that there was no way to make an impact on our own and it would take the entire surf industry to scale this product into a reason- able price. Once we were confident it was ready for commercialization, we pro- duced a small production run for our retail stores and immediately invited other companies to begin testing the material for themselves. The main barrier has been the price, however. The common reason you'd hear for not adopting Yulex is per- formance, which is a falsehood, because you can't tell the difference except for the smell (the Yulex suit smells good).

However, once Patagonia won Wetsuit of the Year and Environmental Product of the Year at the 2015 SIMA (Surf Industry Manufacturing Association) image awards, "Yulex's phone began ringing off the hook," said Hubbard. "And now that there is a more cost-effective version of Yulex available, everybody is jumping on board. Kind of disappointing when you can't see past the bottom line in order to make a change."

\section{Foessel said on DWR:}

The textile industry is desperate for something that actually works. I'm 100 per-cent certain that if we do come up with something that works, companies like North Face would happily adopt the new technology, unless it's really cost prohib- itive. Other brands will follow and all these brands want to change. It's a lot easier to adopt a chemical finish than something agricultural like organic cotton.

On scaling, Graves said,

Our model is to open up BST's solutions to the industry, including our compete -tors. 
We love the model because when the big guys adopt these innovations it scales the environmental benefits and enhances our return on investment. We spent a lot of time talking to the founders to make sure that if we invested, we wouldn't damage BST's relationships with its existing customers who are our com- petitors.

Foessel agreed, "Patagonia's competitors such as North Face don't have any problems with Patagonia being an investor in BST in terms of working with us and future adoption of new technologies."

Patagonia has also worked with major chemical companies - often viewed as poor actors in environmental controversies - throughout its supply chain to drive further scaling of innovations. For example, in 2014, Patagonia began col- laborating with chemical companies through equitable development agreements so that more conservative companies or those with intellectual property would be more willing to "share with us what's really behind the curtain in terms of their mid- to long-term innovation strategy," said Dwyer.

For a brand to reach out to a chemistry supplier is kind of a new thing. Until the brands, which place the order and have dollars on the table, insist that a chemistry gets pulled through their supply chain, it's not going to happen. The idea of going to a chemical supplier and innovating that part of the supply chain is relatively new.

Examples of collaboration with chemical companies included Yulex, where Patagonia innovated at the raw material level (even before rubber was turned into neoprene); DWR and C6 to work with chemical companies for "so long with so many people to make sure the trials were run and the project was done"; and Polygiene for Patagonia's antimicrobial finish. On the latter case, the company worked with Polygiene to co-brand an odor control technology that was on the fabric surface. ${ }^{40}$

\section{The Future}

As the team of leaders prepared to launch their meeting on DWR, they watched several Patagonia employees trot past the conference room with their surfboards in tow. They wondered about Patagonia's DWR efforts that included the company's own efforts, its investment in BST, as well as longer term research on cutting-edge areas like biomimicry.

Specifically, they needed to decide what they should do on the DWR issue. Were their current investments and initiatives the optimal ones for Patagonia and the industry as a whole? Was a transition to C6 the right strategy? Or was it 
actually limiting disruptive innovations? How could Patagonia move beyond incremental improvements? If any of their research streams became successful, how would the company commercialize these new technologies? And how would the company scale the new technology in an industry that was very focused on cost versus environmental responsibility? 


\section{Appendix}

\section{Patagonia Eco-innovation Case Competition}

This case served as the focus of the inaugural Patagonia Eco-innovation Case Competition hosted by the Center for Responsible Business at the University of California, Berkeley, Haas School of Business. In February 2016, proposed solutions to this case were submitted by multidisciplinary teams of graduate students from universities across the United States. A team of Patagonia employees selected eight finalist teams who were invited to present their proposed solutions in person in April 2016 at the University of California, Berkeley. A selection of Patagonia's leadership team, including CEO Rose Marcario, judged these presentations and engaged in questions and answer ses- sion with the student teams.

A team from the University of Michigan won the inaugural case competition with Yale University named runner-up. The following represents the execu- tive summaries from these two respective teams.

University of Michigan team. Kevin Golovin, Aysha Malik, Denise Miller, David Ruebenson, Sarah Snyder, and Ally Stewart, and advised by Professor Ravi Anupindi.

Executive summary. Create an innovative bio-based solution that causes no harm and build the best product.

- To continue providing top performance waterproof gear while minimizing environmental impact, Patagonia should switch from using C6 durable water repellent (DWR) to using an innovative new technology designed by our team at the University of Michigan: "SoyShield," the soybean and silica bio-based superhydrophobic barrier. SoyShield is a fluorine-free, nontoxic, and highly sustainable bio-based coating, created from organic, sustainably sourced soybean oil and silica (sand) nanoparticles, and was designed from the ground up to specifically meet Patagonia's needs of durability, oil repellency, and low environmental impact. The SoyShield technology enables Patagonia to eliminate the use of C6 within the next three years without sacrificing the quality of its gear.

Implement a major solution to an environmental crisis. 
- A five-stage process will govern SoyShield's implementation: Step 1. Complete Lab Testing (one to six months); Step 2. Identify and Screen Suppliers (six months); Step 3. Update Manufacturing Process Technology (three months); Step 4. Encourage Other Companies to Use SoyShield (one to two years); Step 5. Invest in Additional WornWear \& "Recycle Your Raincoat" Ini- tiatives (ongoing).

- SoyShield will replace Patagonia's C6 use in one year, hitting the market by 2017.

Inspire others to maximize the global impact of the solution.

- Once Patagonia establishes a proof of concept, Patagonia will then act as a change agent to lobby other waterproof outerwear retailers to transition to SoyShield, eliminating the use of C6 and C8 by 2019. Channels of influence include both existing networks like the Sustainable Apparel Coalition, Bluesign, and the Fair Labor Association, and bottom-up influence from consumers on social media led by field-testing ambassadors.

- Patagonia can help minimize the spread of perfluorinated compounds (PFCs), which have become ubiquitous - detected in fish, meat, milk products, drinking water, and plants. While researchers continue to strive to understand the longterm side effects of PFCs, epidemiological studies have indicated nega- tive effects of PFCs on glucose, uric acid metabolism, urinary bladder, and prostate cancers. With this research still in progress, Patagonia's impact on minimizing harm to people and the environment is not quantifiable.

- Patagonia must keep pace with European-based outdoor companies such as Vaude and Jack Wolfskin, both of which have committed to eliminating PFCs in their products by 2020. SoyShield ensures that Patagonia and other U.S.based outdoor companies can proactively respond and influence how PFCs are eliminated internationally.

Yale University team. Nitesh Kumar, Laurene Petitjean, Jon Powell, Serena Pozza, and Ranran Wang, and advised by Professor Paul Anastas and Dr. Todd Cort.

Executive summary. Based on (1) Patagonia-provided information, (2) a careful examination of scientific literature and Patagonia's past and existing practices, (3) our focused life-cycle analysis of the textile sector, and (4) our tar-geted market research, we developed two immediate-term and three short- to medium-term solutions (Figure A1) for Patagonia to address its pressing chal- lenges with DWRs in its product lines: 
- Lead the way in understanding and establishing, with a high degree of scientific credibility, the true risks associated with the DWR chemicals currently used (Immediate Solution 1 [I1] and Short- to Medium-Term Solution 1 [M1]);

- Clearly and directly communicate the specific steps that Patagonia is taking to help solve this issue and continuing its tradition of providing transparency to its customers (I1, I2, and M2);

- Forging a strategic alignment with green chemistry researchers, a forwardthinking chemical company (or companies), and the U.S. Environmental Protection Agency's (EPA) Design for the Environment program to accelerate the development of alternatives meeting Patagonia's performance standards (M1);

- To systematically assess and identify unnecessary environmental and human health impacts along the Patagonia's product supply chain and implement solutions accordingly (M2).

Figure A1. Yale team proposed Patagonia solution.

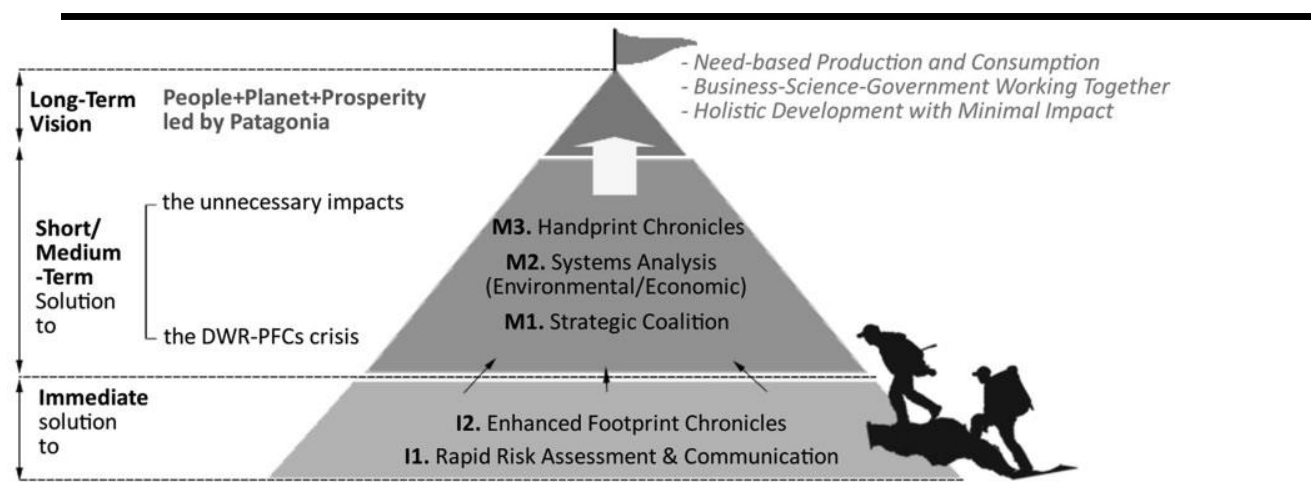

Note: DWR = durable water repellent; PFCs = perfluorinated compounds.

Our solutions address Patagonia's needs and reflect a dynamic coupling of in-house resources and strategic partners. We developed with due care a series of novel yet practical solutions that balance the complex mix of technical and com-mercial tensions evident in this important problem. Long term, we see Patagonia significantly bolstering its already stellar profile in the textile industry broadly, and among its peers specifically, which will drive change well beyond Patagonia's immediate sphere and cascade throughout the world. 


\section{Author Biographies}

Dara O'Rourke is Associate Professor with the Department of Environmental Science, Policy, and Management at the University of California, Berkeley (email:orourke@berkeley.edu).

Robert Strand is Executive Director of the Center for Responsible Business and member of faculty with the Haas School of Business at the University of California, Berkeley. He is also Associate Professor with the Copenhagen Business School Centre for Corporate Social Responsibility (email: rstrand@ berkeley.edu).

\section{Notes}

1. https://www.patagonia.com/us/patagonia.go?assetid=2386.

2. Yvon Chouinard, Let My People Go Surfing (New York, NY: Penguin, 2005), p. 160.

3. https://www.patagonia.com/company-info.html.

4. "Chouinard was one of the leading climbers of the "Golden Age of Yosemite Climbing." "He participated in the first ascent of the North America Wall in 1964 (with Royal Robbins, Tom Frost, and Chuck Pratt), using no fixed ropes ... Chouinard became the most articulate advocate of the importance of style, the basis of modern rock climbing." https://en.wikipedia. org/wiki/Yvon_Chouinard.

5. "Patagonia's Founder on Why There's 'No Such Thing as Sustainability," Fast Company, July 1, 2009, https://www.fastcompany.com/1298102/patagonias-founderon-why-theres- no-such-thing-as-sustainability.

6. Private Canadian competitor, Arc'teryx, was smaller than Patagonia.

7. Founded by Patagonia in 1989, the purpose was to encourage outdoor businesses to con- tribute to environmental organizations. By 2012, the organization had grown to include 170 businesses.

8. $1 \%$ For the Planet consisted of 1,200 members in 48 countries who donated $1 \%$ of revenues to environmental organizations worldwide.

9. Patagonia was the first company to become a B-Corp in December 2011, https://www.bcor- poration.net/community/patagonia-inc.

10. Nicholas Ind, Living the Brand: How to Transform Every Member of Your Organization into a Brand Champion (London, UK: Kogan Page, 2007).

11. Chouinard, op. cit., p. 200.

12. Walmart and Patagonia have partnered in many ways since 2010, http://www.forbes.com/ forbes/2010/0524/rebuilding-sustainability-eco-friendly-mr- 
green-jeans.html.

13. Jill Dumain, "Innovative Strategies to Create a Disruptive Brand," February 24, 2012, https://www.youtube.com/watch?v=vVQ6ghRva38.

14. Referring to the Sustainability Apparel Coalition.

15. Environmental Health \& Safety.

16. "PFOS, PFOA, and Other Fluorochemicals," Patagonia, 2013, https://www.patagonia.com/pdf/en_US/pfoa_and_flourochemicals.pdf.

17. https://en.wikipedia.org/wiki/Perfluorooctanesulfonic_acid.

18. https://en.wikipedia.org/wiki/Perfluorooctanoic_acid.

19. "PFOS, PFOA, and Other Fluorochemicals."

20. Judith Nemes, "Amid Criticism, Patagonia Works to Rid Outerwear of PFCs," November 17, 2012, http://www.judithnemes.com/blog/?p=569.

21. James Politi and Shannon Bond, "Greenpeace Slams Outdoor Clothing Makers," Financial Times, September 7, 2015, http://www.ft.com/intl/cms/s/0/ad0b80e6-55a811e5-9846- de406ccb37f2.html.

22. "Our DWR Problem," Patagonia Blog, September 8, 2015, http://www.thecleanestline. com/2015/09/our-dwr-problem-updated.html.

23. https://chemicalwatch.com/11701/clothing-brands-seek-alternatives-to-long-chain-pfcs.

24. "Our DWR Problem."

25. https://chemicalwatch.com/11701/clothing-brands-seek-alternatives-to-long-chain-pfcs.

26. "PFOS, PFOA, and Other Fluorochemicals."

27. Ibid.

28. Elizabeth Miller, "Patagonia's \$1 Million Bet on Eco-Friendly Water

Repellency," SNews, April 14, 2015, https://www.snewsnet.com/news/patagonias-1million-bet-on-eco-friendly- water-repellency.

29. Patagonia entered into an agreement with Kina'ole Capital Partners to create a \$27 million fund that would purchase more than 1,000 rooftop solar power systems in Hawaii where most homeowners relied on coal and oil for electricity and where electricity was 3 times more expensive than it was in the U.S. mainland. The project would make affordable clean power available to many more people in Hawaii and would benefit the environment.

30. Foessel was on a team that worked at Ciba, a partner of DuPont, to launch the Teflon brand into textiles.

31. "Our DWR Problem."

32. Martin Vilaboy, "Patagonia Invests in DWR Technology Company," April 3, 2015, http:// insideoutdoor.com/patagonia-invests-in-dwr-technology-company/.

33. Mary Catherine O'Connor, "Waterproof, Breathable, and Toxin-Free," Outside, April 21, 2015, https://www.outsideonline.com/1967866/waterproof-breathable-andtoxin-free.

34. https://www.linkedin.com/pub/tetsuya-o-hara/b/738/331.

35. Even though Chouinard did not occupy any official executive position after he 
retired as CEO in 1999, he still played a role in the direction of the company and strategy. He stated that the board drove high-level change at Patagonia, not the CEO. Forest L. Reinhardt, Ramon Casadesus-Masanell, and Hyun Jin Kim, "Patagonia," Harvard Business School Case 711-020, August 2010, p. 3.

36. Patagonia Works Annual Benefit Corporation Report, Fiscal Year 2013, p. 10.

37. Ibid., p. 13.

38. SNews, "Q\&A: Patagonia's Jill Dumain on Why Brands Should Share Environmental- Friendly Tech with Rivals," March 3, 2015, https://www.snewsnet.com/news/qa-patagonias- jill-dumain-on-why-brands-shouldshare-environmental-friendly-tech-with-rivals.

39. Michelle Camp, “An Interview with Patagonia's Director of Environmental Strategy," Sage, October 17, 2013, http://www.sagemagazine.org/an-interview-withpatagonias- director-of-environmental-strategy-jill-dumain/.

40. Polygiene permanent odor control is based on silver chloride made from $100 \%$ recycled sil- ver sourced from photographic and industrial applications. 